\title{
The
}

University

of Chicago

Law Review

\section{Solomonic Judgments: Against the Best Interest of the Child}

\author{
Jon Elster $\dagger$
}

\begin{abstract}
"La principale finesse est de ne vouloir point du tout user de finesse."

"Simplicity is the ultimate sophistication in deciding a child's placement."
\end{abstract}

Few legal situations are as agonizing as child custody disputes in divorce cases. ${ }^{3}$ They are agonizing above all for the parties di-

† Professor of Political Science, The University of Chicago. This paper is part of a project on issues of distributive justice in child custody and child placement, financed by the Norwegian Social Science Research Council. I am indebted to my colleague in this project, Kirsten Sandberg, for useful discussions and invaluable comments, and to Robert Mnookin for helpful advice and criticism. I am also grateful for comments by Kirsti Strom Bull, G. A. Cohen, Tove Stang Dahl, Torstein Eckhoff, Fredrik Engelstad, Helga Hernes, Aanund Hylland, Karl O. Moene, Lucy Smith, and Cass Sunstein, as well as the participants in the Seminar on Ethics and Public Policy at the University of Chicago and in the Legal Theory Workshop at Columbia University.

1 Rene Descartes, 4 Oeuvres de Descartes 357 (Adam and Tannery, eds., 1901).

2 Joseph Goldstein, Anna Freud, and Albert J. Solnit, Beyond the Best Interests of the Child 116 (2d ed. 1979).

s In this article I am almost exclusively concemed with custody in divorce cases, in which the dispute is between the two parents. Many similar problems arise in disputes between the biological parents of a child and a welfare agency or foster parents. I shall occa- 
rectly involved: the parents and the children. For some parents, the child is such an extension of their own persons that being denied custody would be like losing a limb or worse. Although it may not be in the child's interest to give custody to a parent who needs the child that strongly, the point here is simply that feelings often do run high. Even for parents whose identities are less closely bound up with the child, separation is usually traumatic.. In divorce, the dispute over custody exacerbates and feeds upon the other conflicts that are cause or consequence of the decision to separate. Important joint decisions about finances and custody have to be made at a moment when the parents are less likely to agree than at any other time. For the child, a divorce can be doubly painful. Whatever the outcome, it will involve the loss of the regular family life, which, however unhappy for the parents, is usually preferred by the child. ${ }^{5}$ Unless the parents agree on joint custody, the divorce will also involve severely curtailed contact with one parent. In addition, the process of a custody dispute imposes costs of its own on the child by generating painful uncertainty and conflicts of loyalty.

Custody disputes are also highly traumatic for the third parties called upon to resolve them. Judges and welfare officials report that these are among the most difficult cases to decide. ${ }^{6}$ In large part this is so, of course, because the issues are so important to the parties directly involved. But custody decisions are also difficult because they are seldom clear-cut. Indeed, I shall argue that there usually is no rational basis for preferring one parent over another. These two features-the knowledge that the decision will have momentous importance for the parties directly involved and the recognition that it may not be possible to have a rational preference for one parent over the other-conspire to create a psychological tension in decision makers that many will be unable to tolerate. Often, they will resolve this tension by adopting an irrational belief

sionally refer to the latter case, which I intend to discuss at length in another article.

- For a useful review of the psychological literature on the trauma of separation from the child, see David L. Chambers, Rethinking the Substantive Rules for Custody Disputes in Divorce, 83 Mich. L. Rev. 477, 541 (1984).

- In their study of divorced families, Judith S. Wallerstein and Joan Berlin Kelly report that "[o]nly a few children in our study thought their parents were happily married, yet the overwhelming majority preferred the unhappy marriage to the divorce." Judith $S$. Wallerstein and Joan Berlin Kelly, Surviving the Breakup 10 (1980).

- "Any judge or trial lawyer, any forensic psychiatrist or other mental-health specialist will affirm that child custody is, indeed, the ugliest of all litigations." Melvin G. Goldzband, Consulting in Child Custody: An Introduction to the Ugliest Litigation for Mental-Health Professionals ix (1982). 
in the possibility of a rational preference. ${ }^{7}$

There are many issues of this kind in modern societies. ${ }^{8}$ The allocation of scarce and vital medical resources, such as organs for transplantation, is characterized by the same two features and gives rise to similar agonizing. Yet child custody cases are special because there are more of them and, most importantly, because they involve face-to-face confrontation between the claimants. ${ }^{9}$ They are among the most important allocative conflicts in our societies, if we measure importance by the number of people involved and the emotional intensity of their involvement. Yet, in another, more traditional sense, custody conflicts are unimportant. They belong to the private life of individuals, not to their public existence. They are highly idiosyncratic, thus lending themselves badly to organized political action. They impinge little on efficiency, liberty, equality, participation, and other values that traditionally have been at the center of political debate and philosophy.

The major exception to the political unimportance of child custody disputes is that to some extent they have been an issue in the women's liberation movement. Yet feminist writers have, by and large, held ambivalent views on the question. On the one hand, it has been argued that in the long run, the disappearance of the maternal presumption will lead to desirable changes in sex roles and socialization. ${ }^{10}$ On the other hand, it has been said that in the short run, giving men an equal chance to custody is an instance of justice according to Saint Matthew:"11 "unto every one that hath shall be given."12 Perhaps as a consequence of these conflicting perspectives, child custody has taken second place in the feminist movement to issues of discrimination, oppression, and exploitation.

Political philosophers largely have ignored child custody as an issue in distributive justice. The present article, therefore, relies mainly on writings by legal scholars. Currently, legal thinking on

J Jon Elster, Sour Grapes 120 (1983). A working hypothesis, to be explored in further work, is that this reaction generates strong cycles in the importance that courts and welfare agencies assign to the criteria for custody and placement.

- For a general discussion, see Guido Calabresi and Philip Bobbitt, Tragic Choices (1978).

- None of the tragic choices discussed by Calabresi and Bobbitt have this particular feature. See id.

10 See Lenore J. Weitzman, The Marriage Contract 115-20 (1983).

1 See Lenore J. Weitzman, The Divorce Revolution 241-42 (1985).

12 Matthew 25:29. In the present context this means that the more wealthy parent has a greater chance of getting custody. As Robert Mnookin has pointed out to me, the same slogan could be used to characterize the status quo presumption (further discussed below) in custody disputes. 
custody disputes is dominated by two approaches. On the one hand, Joseph Goldstein, Anna Freud, and Albert J. Solnit have had a major impact on the theory and practice of the law by three books that rest on the psychoanalytic theory of child development. ${ }^{13}$ They recommend, notably, that custody should be decided swiftly, irreversibly, and without court-imposed visiting rights to the noncustodial parent, thus enabling the child to have a stable, undisturbed relationship with one adult person. On the other hand, Robert Mnookin has mounted a powerful attack on the principle of "the best interest of the child," arguing that it is too indeterminate to be helpful in legal decisions. ${ }^{14}$ This article draws upon and extends Mnookin's attack. ${ }^{15}$

Two features of child custody disputes render them interesting, even unique, from the point of view of distributive justice: the interest of a third party (the child) and the self-defeating nature of attempts to get custody. Superficially, custody conflicts look like other distributive issues. Who gets the house? Who gets the car? Who gets the child? The last case is different, however, because the object to be allocated also has an interest in the allocation. Although the child may to some extent and for some purposes be considered a consumption good for the parents, ${ }^{16}$ she is also and predominantly a person in her own right.

There is an undeniable tension or paradox here. Prior to conception, it is easy to think of the child as a consumption good or, to the extent that children work, as a capital good. Parents make

1s Goldstein et al., Beyond the Best Interests of the Child (cited in note 2); Joseph Goldstein, Anna Freud and Albert J. Solnit, Before the Best Interests of the Child (1979); Joseph Goldstein, Anna Freud, Albert J. Solnit, and Sonja Goldstein, In the Best Interests of the Child (1986).

14 See Robert H. Mnookin, Foster Care-in Whose Best Interest?, 43 Harv. Educ. Rev, 599 (1973); and especially Robert M. Mnookin, Child-Custody Adjudication: Judicial Functions in the Face of Indeterminacy, 39 L. \& Contemp. Prob. 226 (1975).

15 I have been influenced also by Mnookin's important work on the incentive effects of custody law. See Robert H. Mnookin and Lewis Kornhauser, Bargaining in the Shadow of the Law: The Case of Divorce, 88 Yale L. J. 950, 977 (1979). See also Robert Cooter and Stephen Marks with Robert Mnookin, Bargaining in the Shadow of the Law: A Testable Model of Strategic Behavior, 11 J. Legal Stud. 225, 243-44 (1982).

${ }^{16}$ In the introduction to a recent book on utility and rights, the editor states: "Nor shall I bother with the niceties involved in determining who or what is a person; I shall assume that, whatever view of persons one holds, ordinary, adult humans are persons." $R$. G. Frey, ed., Utility and Rights 3 (1985) (emphasis added). On one view, which stresses the relation between personhood and the capacity for reflective judgment, children are not "persons" but rather "wantons." Harry G. Frankfurt, Freedom of Will and the Concept of a Person, $68 \mathrm{~J}$. Phil. 5, 11 (1971). For my purposes here I need not go deeply into this issue. Policy towards children should protect and enhance their potential for becoming persons in Frankfurt's sense. 
decisions about having children by considering them in these perspectives and by making trade-offs between children and other goods. ${ }^{17}$ Since the child does not yet exist, one does not think of it as a person with unique qualities, needs, and rights. Once the child is born, however, the perspective seems to change. To treat the child as a consumption good for the parents, by deciding on child custody solely according to the needs or rights of the parents, would violate the Kantian principle that persons ought to be treated as ends in themselves, not merely as means for other people.

This intuition is probably at the root of the principle, currently accepted in most Western countries, that disputed custody decisions ought to be settled exclusively or nearly exclusively according to what is in the child's best interest. ${ }^{18}$ The principle is reinforced by the idea that the child is fundamentally innocent, in a sense that applies to neither parent, even if one of them formally has been wronged by the adultery of the other. If, as is often asserted, neither party is in a more substantive sense guilty for the breakup, usually neither is innocent, either.

Against this, I shall argue that following the principle of the child's best interest in fact may be unjust toward the parents. $\mathrm{Pa}$ rental rights and needs could in principle also be relevant in child custody disputes. This is not to say that disputes ought to be settled so as to maximize the total utility of parents and children, even assuming that this concept could be made meaningful. Children do need special protection. But their interests do not trump those of all other parties.

The second unique feature of child custody cases is exemplified by Solomon's biblical judgment. ${ }^{19}$ The crucial piece of evidence he used for giving the child to one woman rather than the other was their behavior in the dispute itself. By making certain claims, or by acceding to certain proposals, one can reveal oneself to have a character that has a bearing on the resolution of the dispute. In Solomon's case, the woman who was willing to have the

${ }_{17}$ Gary S. Becker, A Treatise on the Family ch. 5 (1981).

18 Undisputed custody settlements, resulting from private bargaining and agreement between the parents, are a different matter. "There can be few areas of life where the treatment of children as property rather than as persons is better exemplified. And this has been accentuated by the growing trend towards private ordering of divorce . . . . Outside a slave society commercial contracts are not concerned with the disposal of human beings: bargains about custody and access are." M. D. A. Freeman, The Rights and Wrongs of Children 192, 198 (1983).

19 1 Kings 3:16-28. 
child cut in half thereby revealed herself ineligible for custody. One may wonder whether Solomon would have carried out his announced decision to cut the disputed child in two, had both women agreed to that proposal. Should we assume that Solomon, like the God of the Old Testament, had perfect insight into the hearts of men and women so that he knew he would not have to carry it out? ${ }^{20}$ Or could it be that he was outguessed by the woman who declared that she would rather give up the child than have it cut in two?

Similar issues arise in modern custody litigation. For example, it has been argued that "[i]f people are indeed litigating for joint custody [i.e., if one parent demands joint custody against the wish of the other], they are generally not likely to be candidates for it."21 Nevertheless, many American states allow one parent to claim joint custody against the wish of the other. When this is coupled with a "friendly parent" provision, to the effect that custody should preferentially be given to the parent who has demonstrated willingness to share custody or to give extensive visiting rights - the outcome may be that parents who don't want joint custody ipso facto reveal themselves as not fit for sole custody either. This creates a dangerous incentive for strategic behavior. ${ }^{22}$

In addition, a Solomon-like judge might refuse custody to a parent whose tactics involve procrastination or derogation of the other parent. Since both tactics can be expected to impose additional pain on the child, the conscious use of them shows a lack of concern for the child that disqualifies the parent for custody. Thus,

${ }^{20}$ See Steven J. Brams, Biblical Games: A Strategic Analysis of Stories in the Old Testament 118, 123 (1980). An interesting reference to the "Solomon syndrome" appears in Garska v. McCoy, 278 S.E.2d 357, 362 (W.Va. 1981).

${ }^{21}$ Richard A. Gardner, Joint Custody is Not for Everyone, in Jay Folberg, ed., Joint Custody and Shared Parenting 63, 70 (1984) (material in brackets added).

${ }^{22}$ See Joanne Schulman and Valerie Pitt, Second Thoughts on Joint Child Custody: Analysis of Legislation and Its Implications for Women and Children, 12 Golden Gate Univ. L. Rev. 539, 550-51 (1982):

The parent requesting joint custody over the opposition of the other parent is given an unconscionable bargaining lever. A parent who does not believe joint custody would be in his or her child's best interest is put into a negotiating position of either 'accepting' joint custody or risking the loss of custody altogether in a contested trial.

Ironically, a parent who is least fit for custody and care of child benefits the most from this type of statute. A parent opposed to joint custody might be more willing to risk loss of sole custody if she or he feels that the other parent is capable of providing sufficient care for the child. However, the parent opposed to joint custody cannot, and probably will not, take the risk when an award of custody to the other parent would not provide minimally sufficient care for the child. Thus, the more 'unfit' the parent requesting joint custody, the more bargaining leverage that parent gains under this type of statute. 
Solomon's method - the use of behavior in custody proceedings to decide custody-can result in a Catch-22. The more forcefully a parent presses a custody claim, the more he proves himself unfit for custody.

On reflection, this simple rule of decision of course must be rejected. Derogation, if successful, detracts from the fitness of the derogated parent, not only from that of the derogating one. As long as appeals and adjournments are allowed by the law, presumably because they can serve the cause of justice, it would be perverse to punish a party for making use of them. Yet there is a core of truth in the argument. How, indeed, can a parent claim to represent the child's best interest if the institutional machinery for making the claim works against that very interest? I argue below that the paradox should be resolved by changing child custody legislation, not by allowing the judge to infer character from behavior during litigation.

In this article, I examine the rule that custody is to be determined according to the best interest of the child. In section I, I offer a brief overview of past and present principles of child custody legislation in some Western countries. In section II, I dispute the principle that custody ought to be decided solely by considering what is in the best interest of the child. I argue that the principle is indeterminate, unjust, self-defeating, and liable to be overridden by more general policy considerations. In section III, I survey, in a somewhat speculative vein, some tactics used by courts in order to circumvent these undesirable features of the principle. Finally, in section IV, I consider various alternatives to the best interest principle, and a number of criteria for evaluating them.

\section{The Route Toward the Best Interest Principle}

Historically, the laws regulating child custody in divorce cases have reflected concern for the rights and needs of both parents and children. ${ }^{23}$ The absolute paternal preference rule that dominated British legislation up to the end of the nineteenth century derived from the father's dominant right in all family matters. Although an abusive father might lose his legal rights to custody, courts could not adjudicate a custody dispute in favor of a wife. The protection of children was kept separate from the settlement of private cus-

${ }^{23}$ For a useful survey of the British legislative history, see Susan Maidment, Child Custody and Divorce chs. 4, 5 (1984). For brief remarks on the American development, see Mnookin, 39 L. \& Contemp. Prob. at 233 (cited in note 14). 
tody disputes. ${ }^{24}$ One writer describes as "the highpoint of the "sacred rights of the father" "25 the decision in Re Agar-Ellis:" "When by birth a child is subject to a father, it is for the general interest of families, and for the general interest of children, and really for the interest of the particular infant, that the Court should not except in very extreme cases, interfere with the discretion of the father."27 Although in this passage the right of the father is grounded in broader instrumental considerations, it was in general conceived as a natural right founded on the inherent superiority of men over women..$^{28} \mathrm{We}$ may note in the cited passage the distinction, which will concern us later, between what is in the interest of children generally and what is in the interest of the particular child under consideration.

In nineteenth-century American law the paternal preference rule did not take hold. Instead, a fault-based presumption emerged: "The children will be best taken care of and instructed by the innocent party" to a divorce. ${ }^{29}$ Like the paternal preference rule, the fault-based principle was grounded in the best interest of the child; however, there is no doubt that overtones of compensatory and retributive reasoning were present. While the fault-based principle never had a central status in Britain, it always had some force. ${ }^{30}$ As late as 1962, "the Court of Appeal allowed a father's appeal against a care and control order to the adulterous mother 'as a matter of simple justice . . . Whilst the welfare of the children is the first and paramount consideration, the claims of justice cannot be overlooked." "si

In this century the maternal preference rule gradually emerged as the dominant doctrine in most Western countries. It often was accompanied by the proviso that it applied especially or only to cases involving young children. ${ }^{32}$ The maternal preference or presumption rule was, like the other rules discussed above, justified on the grounds of the interests of the child..$^{33}$ This appears,

\footnotetext{
${ }^{24}$ Mnookin, 39 L. \& Contemp. Prob. at 234 n.33 (cited in note 14).

${ }^{25}$ Maidment, Custody and Divorce at 98 (cited in note 23).

${ }^{26} 24$ Ch. D. 317 (1883).

${ }^{27}$ Id.

${ }^{28}$ Maidment, Custody and Divorce at 109 (cited in note 23).

${ }^{28}$ Mnookin, $39 \mathrm{~L}$. \& Contemp. Prob. at 234 (cited in note 14), quoting Joel Bishop, Commentaries on the Law of Marriage and Divorce 518, 520 (1852).

so Maidment, Custody and Divorce at 154 (cited in note 23).

s1 Id. at 15, quoting Lord Denning in $\operatorname{Re}$ L, 3 All ER 1, 4 (1962).

${ }^{32}$ Mnookin, 39 L. \& Contemp. Prob. at 235 (cited in note 14); Maidment, Custody and Divorce at 156 (cited in note 23).

${ }^{33}$ See, e.g., Mnookin, 39 L. \& Contemp. Prob. at 235 n. 41 (cited in note 14); Maid-
} 
moreover, to have been virtually the only justification, unlike the other rules that have also appealed to parental rights as an independent justification.

Like any presumption, that of maternal preference was rebuttable. How much it takes to rebut it, varied from country to country and from court to court. In the United States, rebuttal often has required a showing of maternal unfitness in some absolute sense, sometimes shading, however, into a contest of relative fitness. ${ }^{34}$ In Norway, the law stipulated that the presumption applied only when there was absolute uncertainty as to which parent was the more fit, but lower courts frequently (and the Supreme Court occasionally) interpreted the presumption to offset some preponderance of probability, well short of certainty, that the father was best suited. ${ }^{\text {ss }}$

The maternal preference rule contained the seeds of its own destruction. By resting exclusively on considerations of the child's best interest, it invited lawmakers to turn that interest into the explicit criterion for custody adjudication in each and every case. Why rest content with the rule of thumb that the interest of children is in general best served by maternal custody, when finely tuned ways of serving the interest of each particular child are available? Why not judge each case on its merits? Moreover, the incorporation of the best interest of the child as a principle for adjudication, and not simply for legislation, has desirable incentive effects. Under the maternal preference rule, the spectre of divorce did not give either parent an incentive to take good care of the child during the marriage.$^{36}$ Usually the mother could count on getting custody unless she behaved very badly, and the father knew that no efforts on his part could give him a chance. Under the new rule, it was no longer true that caring for the child was

ment, Custody and Divorce at 156 (cited in note 23).

s4 Mnookin, 39 L. \& Contemp. Prob. at 235 n.41 (cited in note 14).

ss L. Smith, Foreldremyndighet og Barnerett ("Parental Governance and Children's Law") 368 (1980). Another possibility is that the presumption could be rebutted by a demonstration that the father was clearly and certainly more fit, even assuming that the mother passed the threshold of absolute fitness. For a discussion of presumptions of varying strength, see Edna Ullmann-Margalit, On Presumption, 80 J. Phil. 143, 152 (1983). David Chambers discusses how a primary caretaker presumption similarly could be understood as requiring, for its rebuttal, (1) a showing of unfitness; (2) "clear and convincing evidence" that the other parent is more fit; or (3) a preponderance of evidence pointing to the other parent as the more fit. See Chambers, 83 Mich. L. Rev. at 562 (cited in note 4).

se For this statement to be false, two conditions have to obtain: the presumption must be taken in a very weak sense and the courts must very seldom find themselves in a state of absolute uncertainty. 
superfluous for the mother and pointless for the father.

The demise of maternal presumption, and its replacement by the principle that custody ought to be decided according to what is in the best interest of the child, occurred in several countries some time in the 1970s. The best interest principle often is formulated in a way that allows some scope for other criteria. ${ }^{37}$ In Britain, the child's welfare should be the "first and paramount" consideration. ${ }^{38}$ In Norway, the decision shall "mainly" consider the interests of the child. ${ }^{39}$ It would appear that the other criteria, whatever they are, are not simply intended to function as tiebreakers when the interest of the child is equally well served with either parent. In principle, a slight difference with respect to what serves the child can be offset by large differences in other respects. But the laws are rarely explicit on the nature of the trade-off and on the nature of the other criteria.

The demise of maternal preference also must be seen in the broader perspective of the feminist movement. The idea of equality between the sexes was difficult to reconcile with the survival of a maternal presumption. Several arguments seem to have been at work here. First, there was the view that when women claim the abolition of male privilege, they also must, to be consistent, accept the abolition of any female privileges that may exist. Against this idea, but pointing to the same conclusion, it was argued that the maternal presumption was a burden rather than a privilege. ${ }^{40} \mathrm{Al}$ though formally the rule involved nothing more than the right to custody, it went together with and reinforced the view that taking care of children is a woman's job. More generally, the presumption was part of a network of sex roles that can prevent women from forming autonomous career plans and professional expectations.

The interpretation and implementation of the best interest principle have been governed by various hypotheses that have sometimes acquired the status of informal presumptions. Certain psychological theories, in particular, have come to be seen as "legislative facts" that can be used to guide decisions without any need to consider the facts of each individual case. ${ }^{41}$ The psychological

${ }^{37}$ For a survey of custody legislation in the United States, see Mnookin, 39 L. \& Contemp. Prob. at 233-37 (cited in note 14).

38 See Maidment, Custody and Divorce at 14 (cited in note 23).

39 Lov 8 April $1981 \mathrm{nr} 7$ om barn og foreldre $\$ 34$ (Law About Children and Parents of April 8, 1981 no. 7 \& 34).

10 See Weitzman, The Marriage Contract at 115 (cited in note 10); Weitzman, The Divorce Revolution at 231 (cited in note 11).

41 For a discussion of the notion of "legislative facts," see Jane W. Ellis, Evaluating the 
theories of John Bowlby on the importance of the mother-child relationship, which formerly served to justify maternal preference legislation, are no doubt occasionally still used as legislative facts in adjudication. ${ }^{42}$ The present conventional wisdom is, however, to rely on the psychoanalytic views of Goldstein, Freud, and Solnit, for whom continuity of the parental relationship is all-important. This doctrine creates what almost amounts to a presumption for the status quo-to award custody to the parent with whom the child is living (and has been living for some time) at the time of dispute. ${ }^{43}$ It also seems to underlie the primary caretaker (or caregiver) assumption that is emerging in some American states, such as West Virginia and Oregon. ${ }^{44}$ Thus in actual adjudications the best interest principle is not always implemented in a case-bycase, unstructured, or discretionary manner.

\section{Against the Best Interest of the Child}

This section presents arguments against the principle that the best interest of the child ought to be the sole, main, or first and paramount consideration in custody decisions. First, following Robert Mnookin, I emphasize the indeterminacy of the principle: in many cases, perhaps most, it simply does not yield a decision. Second, I argue that even when the principle is determinate, it is liable to yield unjust decisions by neglecting the rights and needs of the parents. Third, I argue that the principle is self-defeating, in that finely tuned consideration of the best interest of each particular child is likely to impose "process costs" that on balance tend to

Expert: Judicial Expectations of Expert Opinion Evidence in Child Placement Adjudications, 5 Cardozo L. Rev. 587, 605 (1984). See also Goldstein et al., In the Best Interests at 60 (cited in note 13).

12 For the role of "Bowlbyism" in English custody cases, see Maidment, Custody and Divorce at 182 (cited in note 23). Maidment also offers a "sociological explanation for Bowlby's reception, that it served economic and political interests in the post-war world to remove women from the labour market, and the maternal deprivation theory thus coincided with a political desire to get women back into the home." Id. at 8 . In the absence of a demonstration that the persons with labor-market oriented reasons to diffuse Bowlby's doctrine also had the intellectual and academic power and opportunity to do so, I remain unconvinced by this functional explanation. For a recent survey of the literature on maternal deprivation, see Chambers, 83 Mich. L. Rev. at 515 (cited in note 4).

${ }^{43}$ For a critical discussion of the doctrine of developmental connectedness, see Jerome Kagan, The Nature of the Child ch. 3 (1984). For a similarly critical discussion of the status quo principle in custody decisions, see Maidment, Custody and Divorce at ch. 8 (cited in note 23).

14 Notably, see Garska, 278 S.E.2d 357. For favorable comments, see Goldstein et al., In the Best Interests at 24, 63 (cited in note 13); and especially Chambers, 83 Mich. L. Rev. at 527 (cited in note 4). 
make children worse off. Last, in a somewhat different vein, I point out cases in which the best interest of the child must take second place to more general considerations of public policy. These arguments are wholly negative. The positive argument for an alternative principle is developed in section IV.

\section{A. The Principle Is Indeterminate}

For the sake of simplicity, this section compares only two custody options: paternal and maternal custody. The arguments developed below also apply if we admit more options (joint custody, splitting of siblings). The question is whether a court can decide which of the two options corresponds to the child's best interest. As in any decision problem, a determinate answer will in general ${ }^{45}$ require the following conditions to be satisfied:

(1) all the options must be known;

(2) all the possible outcomes of each option must be known;

(3) the probabilities of each outcome must be known;

(4) the value attached to each outcome must be known.

The first condition is satisfied ex hypothesi. Mnookin argues that we cannot expect any of the others to be. ${ }^{46}$

1. Outcomes of each option. Consider first the set of possible outcomes. If, say, custody is given to the mother, a great number of things could happen to her, and she could do a great number of things (as could the father) that would have an impact on the welfare of the child-so great, in fact, that we cannot even begin to list them. Hence the expected utility calculus cannot be carried out.

This objection, while valid, is in a sense too strong. In most decision problems, each of the options is accompanied by a number of unknown and essentially unknowable possibilities whose materialization depends upon the future development of the universe. When trying to make up one's mind, one has to assume that these and other unknowable factors on each side cancel out, so that one can concentrate attention on the knowable ones. Even among the latter, one has to focus mainly on the known ones because of the direct costs and opportunity costs of collecting and processing information. The ensuing decision, although not ideally rational from

45 In special cases they need not all be satisfied. Thus if the comparison yields the same outcome for any set of probabilities attached to the outcomes, or for any (reasonable) value ordering, the indeterminacy of fact or value need not bother us.

${ }^{48}$ Mnookin, 39 L. \& Contemp. Prob. at 257 (cited in note 14). 
the point of view of an omniscient observer, will at least be as rational as can be expected. Similarly, the custody judge should not let herself be paralyzed by all the things that might conceivably happen and that would be relevant if they did happen. She is justified in fixing her attention on a small number of things that plausibly might happen.

2. Probability of each option. Consider next the objection from indeterminacy of probability. It might appear as if the above reasoning against Mnookin's first objection (that is, the indeterminacy of possible outcomes) automatically provides a reply to this one, since in order to decide that an outcome is "plausible," one must know something about how probable it is. I believe, however, that the plausible can be identified in other ways. If a consequence is predicted by a partial theory, that is, one that is valid other things being equal, we may regard it as plausible even if we do not have a more general theory that would allow us to assess its probability. ${ }^{47}$ Once the plausible outcomes have been identified, we can go on to ask whether their probabilities can be assessed. If they can, and if values can confidently be attached to the outcomes, the expected utility calculus can be carried out and one option singled out as the best, except that in the special case that both have the same expected utility. If values but not probabilities can be attached to outcomes, we have a problem of decision making under uncertainty (in the technical sense in which it differs from decision making under risk with known probabilities).

In such problems, a natural response is to play safe, which in the present case means giving custody to the parent with whom the child's worst plausible future will be best. This criterion would tend to reward emotional and financial stability. It is consistent with the axioms of rational decision making under uncertainty, ${ }^{48}$ but so are other criteria that would point in different directions. It is just as rational, for instance, to choose the option under which

17 See Jon Elster, Explaining Technical Change 201 (1983). Also, if we can tell a smooth scenario (one that does not rest on accidents and coincidences) about how $\mathrm{X}$ could lead to $\mathrm{Y}$, then $\mathrm{Y}$ is a plausible outcome of $\mathrm{X}$ even if we cannot say anything about how probable it is that $X$ will lead to $Y$. See Daniel Kahneman and Amos Tversky, The Simulation Heuristic, in Daniel Kahneman, Paul Slovic, and Amos Tversky, eds., Judgment Under Uncertainty 201-08 (1982).

18 See R. Duncan Luce and Howard Raiffa, Games and Decisions 296 (1967) (the Arrow-Hurwicz criteria). Aanund Hylland has pointed out to me that it is sometimes possible to improve on the Arrow-Hurwicz criteria if the uncertainty attaches to the choice between theories each of which assigns definite probabilities to the outcomes. This observation could have some relevance to the present problem, in which a large part of the uncertainty derives from the unsettled state of psychological theory. 
the child's best plausible future is as good as possible.

3. Values attached to outcomes. Even if one is able to attach probabilities to outcomes, or to justify a specific criterion of decision making under uncertainty, a third objection remains: the impossibility of attaching values to outcomes. Even if the child were as fully capable as an adult person of expressing an informed preference over possible futures, the ranking might be partially indeterminate. It is a mistake to assume that having complete preferences-that is, being able to compare and rank all pairs of outcomes-is part of what it means to be rational. In particular, comparability may fail when the outcomes are large chunks of a life rather than small, isolated events. Since the extent to which preference orderings approach completeness increases with one's experience and exposure to a large and varied set of alternatives, the early choices that lead to that exposure are less likely to stem from complete preferences. The child, having very little experience, can be expected to have large gaps in his preference ordering.

If a judge or psychologist tried to make an informed choice on behalf of the child, she in general would have to add some preferences of her own. Although she might be justified in correcting for the child's tendency to seek immediate gratification, she would in addition have to engage in morally objectionable paternalism. Her decisions often would amount to telling one of the parents: "Because we don't like your lifestyle, you don't get the child." It would not help much to instruct the judge to make the decision that the child will approve later, on the basis of more fully developed preferences, assuming such prediction to be possible. ${ }^{49}$ Since those preferences will largely depend on the decision made, the instruction may not discriminate sufficiently between the options. ${ }^{50}$ In any case, it is not realistic to assume that judges will be able to predict the future preferences of the child.

There is, however, a different and, I believe, superior way of approaching the problem of the child's best interest. Instead of being guided by substantive preferences and choices that are imputed to the child, one could seek to achieve the more formal goal of protecting the child's opportunity and ability to make choices. On this view, children should be allowed, as far as possible, to reach maturity with a maximum of potentialities and the auton-

19 This solution has been proposed by Chambers. See 83 Mich. L. Rev. at 493 (cited in note 4).

so Chambers recognizes this problem. Id. at 495. See also Jon Elster, Ulysses and the Sirens 47 (rev. ed. 1984). 
omy needed to choose which of them to develop. At that point, it is up to them what they choose to make of their lives, but one should not knowingly preempt the choice. The child needs physical health and material well-being to assure survival and development of his potentialities, and emotional care as a condition for autonomous choice. Whatever the interests of the child ultimately turn out to be, he has an antecedent interest in being able to choose without material or psychological constraints. ${ }^{51}$

In most cases, this liberal, pluralist criterion will not yield a determinate preference for one parent. It can, however, serve to exclude some parents as unfit in an absolute sense. To be unfit for custody, a parent must be shown to have neglected the physical needs of the child, to have physically abused him, to be financially unable to provide for him, or to have character traits that render the parent emotionally inadequate. The meaning of the last clause is of course controversial..$^{52}$ I submit that it should be interpreted narrowly, so as to include little beyond clinically demonstrable psychic disorders. Psychology is an undeveloped and controversial discipline even at the best of times; and the context of a custody dispute is far from the best time to study the dispositions of children and parents.

Although I shall adopt this liberal principle in the following discussion, it poses certain problems. It counts against a parent who, for instance, intends to give the child a very strict religious upbringing that, for all practical purposes, preempts the child's later choice of religion. This result may seem unacceptable, since parents who remain together have the right to raise their children as strictly as they want. I believe, however, that this right rests on an essentially rule-utilitarian argument that does not apply to divorced families. Were it possible, within the undivorced family, to ensure the child's autonomy in religious (or political) matters without interfering unduly with family life, I believe one ought to do so. We do not do so, however, because the degree of state control

s1 This idea is similar to and partially inspired by John Rawls's notion of "primary goods." See John Rawls, A Theory of Justice 90 (1971). Chambers offers a similar proposal, with emphasis on children's competence to act rather than on their autonomy to choose. See 83 Mich. L. Rev, at 497 (cited in note 4). I suggest, however, that autonomy is the more basic value, since it ensures competence without being required for it.

s1 As an Irish court stated: "A hot-tempered, emotional, difficult, incompetent wife may be a more suitable person to leave custody than a cold, unsympathetic, self-righteous and very able husband." See Smith, Foreldremyndighet og Barnerett at 430 (cited in note 35). See also Jon Elster, Sadder but Wiser? Rationality and the Emotions, 24 Soc. Science Inform. 375 (1985). 
and intervention required would be very harmful to family life and, ultimately, to children's autonomy. The remedy would be worse than the disease. In disputed custody cases, on the other hand, judicial intervention is already a fact, and application of the liberal principle adds no disruption to a family that has already broken up. ${ }^{\text {s3 }}$

My conclusion, then, is that the best interest principle is usually indeterminate when both parents pass the threshold of absolute fitness. This does not imply that a highly qualified expert, if allowed to observe the family prior to dissolution, would be unable to predict which parent would be more fit for custody. It implies, more weakly, that courts will not be able to make this prediction on the basis of the behavior of the parents during an exceptionally stressful period.

Yet I do not exclude that sometimes the evidence is sufficiently clear-cut to say that one of two fit parents is fitter than the other. I do not believe that these cases are frequent, but I might be wrong. Hence in what follows I shall often assume, contrary to what I have been arguing, that differences in parental fitness can be routinely ascertained by the court, to argue that even on this assumption the best interest principle should be rejected.

\section{B. The Principle is Unjust}

Barring siblings, a custody case involves three persons, all of whom have a strong interest in the decision. Yet according to the best interest principle, the child's welfare is the dominant consideration. The law does not take any account of the needs and rights of the parents, except to the extent that it admits the child's interest to be the "first and paramount" rather than the "sole" criterion. One might think, given the argument from indeterminacy, that there is a wide scope for considering parental interests. Yet this is not how the law works, as I argue in section IV below. Judges make an effort to wring determinate results from the best interest principle. ${ }^{54}$ Although in doing so they may be sensitive to parental interests, they usually do not cite these as independent

ss This point is overlooked by Ellen Canacakos when she writes:

Since the state's right to interfere with [parental] rights within the family is limited by a principle far more restrictive than "the best interest of the child", it is hard to see why state interference should become any less restricted after divorce.

Ellen Canacakos, Joint Custody as a Fundamental Right, in Folberg, ed., Joint Custody and Shared Parenting at 223 (cited in note 21).

b4 See section III below. 
considerations, but smuggle them in under the guise of the best interest of the child.

Even when the consideration of the child's best interest yields a determinate preference for one parent, parental interests ought also to be considered. Some of these derive from the rights of parents, and others from their needs.

One example of a rights-based claim is Lord Denning's admonition that in cases of adultery, one must consider the "claims of justice" in addition to the welfare of the child. In general, this is a dubious argument. For one thing, relations between spouses are usually so complex that an act of adultery does not in itself create one guilty and one innocent party. ${ }^{55}$ For another, adultery, when blameable, is more properly punished through the financial settlement than by the loss of custody. Unlike other forms of behavior, discussed below, which one might want to reward by the granting of custody or punish by the denial of it, adultery generally is not a child-related action. There is, nevertheless, the incentive argument that predictable loss of custody will be a more potent deterrent to adultery than will mere financial loss. The main thrust of this argument from incentives, as usually deployed, is the stabilizing impact on family life in general and on the welfare of children in particular. Although the welfare of a given child may be best promoted if custody is given to an adulterous parent, the welfare of children in general may require a presumption, which could be more or less strong, against this practice.

Other rights-based considerations are more compelling. Thus if one parent, usually the mother, has devoted crucial years to child care and perhaps given up her career to do so, it seems prima facie right that she should get custody. Note that in this case, unlike that of adultery, the rights-creating behavior is directly related to the child. It would be odd to give custody to one parent on the ground that he or she has behaved meritoriously in matters unrelated to the child-for example, by taking care of elderly relatives. To use child care as an argument for child custody seems more relevant. By linking expected custody to care, the quality of the latter-and consequently of the former, should the case arise-will be enhanced. In addition to this argument, which appeals to the general interest of children, there is an independent reason in terms of fairness to the primary caretaker (when there is one). To award custody to the other parent would often be justice according

ss Maidment, Custody and Divorce at 16 (cited in note 23), citing Lord Justice Ormrod. 
to Saint Matthew.

Another rights-based principle is that custody should not be given to a parent who has used illegal tactics of abduction or procrastination to create a fait accompli in order to benefit from the status quo presumption. This principle is like the adultery argument in that it refuses custody to a wrongdoing parent, and like the child care argument in that the behavior in question is related to the child. Against this principle, however, it has been argued that the proper punishment for such behavior should not be denial of custody, since this would also, given the status quo presumption, be a punishment of the child. ${ }^{\mathrm{B}}$ Disregarding the difficulty that other ways of punishing the parent also may hurt the child, I believe there is an argument for making the punishment fit the crime. Other things being equal, the punishment ought to be chosen so as to render the illegal action entirely fruitless, that is, to nullify its immediate purpose of gaining custody, and not simply to nullify any net gain to offender by imposing costs at least as large as the immediate gain. ${ }^{57}$ Among the other things that may not be equal are, of course, the costs that punishment or reward may impose on the child.

The preceding considerations are based on the rights of parents. Considerations of parental needs or welfare also may be relevant. ${ }^{58}$ Imagine a case in which the best interest of the child creates a slight but detectable preference for paternal custody, whereas the welfare loss for the mother from not getting custody would be much larger than what would be suffered by the father if he were denied custody. Imagine also that the absolute welfare level of the mother would be very low were she to be denied custody. In that case, strong welfarist arguments support maternal custody.

In general, however, welfare-based arguments face formidable difficulties. In principle, parental welfare should count for more than parental rights. The latter have little weight unless backed by

${ }^{B 6}$ See Goldstein et al., In the Best Interests at $174 \mathrm{nn} .2,4$ (cited in note 13).

Bz In arguing for this view, one cannot simply appeal to the principle that "no man may profit by his own wrong," Ronald Dworkin, Taking Rights Seriously 23 (1977), since this does not distinguish between immediate profits and net profits. Rather, one must point to the difficulty that courts face in ascertaining the subjective value of the illegal action and, hence, in imposing a cost equivalent to it. The only way to be certain that the offender does not profit from the offense is to undo it.

${ }_{88}$ The distinction between rights and welfare is not absolute, since the belief that one's rights have been violated may contribute to the misery of being denied custody. The violation of a right may cause more suffering than the nonexercise of the right following from its voluntary waiving. 
the former. Consider a mother who (1) in the past has sacrificed some of her own welfare to take care of the child, but (2) would not suffer much in the present if she did not get custody, and (3) has a welfare level in the present no lower than what she could be expected to have had in the absence of those past sacrifices. Her rights-based claims, although not totally invalidated by the lack of links to the present, are, it seems to me, weakened. ${ }^{59}$ If her husband who, let us assume, did not make any sacrifices in the past, would suffer greatly in the present from not getting custody, his claim should take precedence. As an objection to this reasoning, however, one can cite the tendency, known to every divorce lawyer, towards strategic misrepresentation of preferences. ${ }^{60}$ As stated above, the forward-looking argument from needs is much less robust than the backward-looking argument from rights. It seems best, therefore, to use rights as a proxy for needs, even if on firstbest principles one would want to discount rights not backed by needs.

In actual practice it will be difficult to apply the welfare criterion, not only because one can virtually never point to "slight but detectable" differences in parental fitness, but also because of preference revelation problems. Whereas rights-based arguments build on verifiable statements about past behavior, needs-based arguments rest on less verifiable, strategically manipulable statements about future welfare. If, as is frequently the case, the parent most in need of the child is also the primary caretaker, rights-based arguments can serve as proxy for the needs-based ones, but otherwise it may be difficult to give legal force to the latter. One could also cite the well-known tendency of the human mind to lessen its affections when their object falls out of reach. This, however, is a dangerous argument, to be used, if at all, with much circumspection. ${ }^{61}$

BD Both the second and third conditions are needed to weaken the present rights-creating force of past sacrifice. If condition (2) is not satisfied, one might still want to award custody to the mother to offset the present welfare losses from past sacrifices. To give custody to the father on the ground that he would benefit more would, once again, be justice according to Saint Matthew. If condition (3) is not satisfied, maternal custody could be justified as compensation for past sacrifices.

so See Richard Neely, The Hidden Cost of Divorce: Barter in the Court, New Republic 13 (Feb. 10, 1986); Mnookin and Kornhauser, 88 Yale L. J. at 972 (cited in note 15); Weitzman, The Divorce Revolution (cited in note 11).

-I I have argued elsewhere that a policy maker should not invoke predictable changes of the citizens' preferences to justify measures that the citizens do not want ex ante. See Elster, Ulysses and the Sirens at 82-83 (cited in note 50); Elster, Sour Grapes at $113 \mathrm{n} .8$ (cited in note 7). 
The child's welfare and the parents' rights and needs all give rise to prima facie claims that must be balanced against each other. In balancing the child's welfare against that of the parents, I believe we can draw some useful lessons from more general theories of distributive justice. Two well-known extreme views are the utilitarian principle that one ought to maximize the sum total of welfare $^{62}$ and Rawls's principle that one ought to maximize the welfare of the worst-off group in society. ${ }^{63}$ Each of these principles seems intuitively unacceptable. ${ }^{64}$ Utilitarianism has the unpalatable consequence that we might be justified in sacrificing individuals for the sake of the general good. The maximin principle of Rawls has the equally counterintuitive implication that one would be justified in reducing almost everybody's welfare a great deal for the sake of a slight increase in the welfare of the worst off. Roughly speaking, utilitarianism offers too little protection to the vulnerable, while maximin justice offers too much. The commonsensical attitude, to which most nonphilosophers seem to subscribe, is to protect the disadvantaged at the expense of the well off, but not if the gains are unreasonably small compared to the costs. Common sense, of course, has no theory to explain what "unreasonably" means here, which is why philosophers would dismiss the view as ad hoc and unprincipled. Yet I submit that in making actual allocative decisions we are constantly forced to make intuitive evaluations of what is and what is not an acceptable trade-off of costs and benefits.

Applied to child custody, this reasoning suggests that one should avoid two extremes. The custody decision should not be made on utilitarian principles, with the goal of maximizing the total welfare of the family members. The child needs special protection. That protection should not, however, extend to small gains in the child's welfare achieved at the expense of large losses in parental welfare. Assume, for instance, that the parents are equally fit ${ }^{65}$

62 John C. Harsanyi, Cardinal Welfare, Individualistic Ethics, and Interpersonal Comparisons of Utility, $63 \mathrm{~J}$. Pol. Econ. 309-21 (1955).

is Actually, Rawls refers to primary goods, not to welfare; but since there are several primary goods, it is hard to see how one could avoid some welfarist considerations when two bundles of primary goods, each of which dominates the other with respect to one good, must be compared.

4. For experimental evidence that people do indeed perceive both principles as too extreme, see M. E. Yaari and M. Bar-Hillel, On Dividing Justly, 1 Soc. Choice \& Welfare 1 (1984); Norman Frohlich, Joe A. Oppenheimer, and Cheryl Eavey, Laboratory Results on Rawls' Distributive Justice, 17 B.J. Pol. Sci. 1 (1987).

es Note that this is a much stronger statement than saying that we cannot tell whether one parent is more fit than the other. 
except that one of them earns twenty percent more than the other. The child can be expected to be somewhat better off with the parent with the higher income, yet one might feel justified in giving custody to the other parent if having custody means much more to him. Let me repeat, however, that I am arguing about a case that I really do not believe will arise, since I do not believe it is possible to make such finely tuned comparisons of parental fitness.

\section{The Principle is Self-Defeating}

Another argument against the "best interest of the child" principle is that by promoting the interest of the child in a particular case, one may work against the interests of children in general. This perverse result can come about in two ways: if legislators neglect the distinction between act-oriented and rule-oriented principles, and if they neglect the costs of legal decision making.

1. Act and Rule. The distinction between act utilitarianism and rule utilitarianism-between searching on each occasion for the act that maximizes utility and searching for a rule that if followed on all occasions will maximize utility-is a familiar one. The two approaches suggest different courses of action because they have different effects on expectations and incentives. ${ }^{66}$ In particular, if one seeks the best decision in each individual case, more cases may arise. Given that a house has been destroyed by a flood, social welfare may be maximized by society providing the owner with a cheap loan to rebuild it at the same site, yet it might be better if society announced that it would never do this, for then fewer houses would be built in these areas.

In the present case, we must consider restricted versions of act and rule utilitarianism that take account only of the welfare of children. It might seem as if rule-oriented considerations are irrelevant here, since children cannot be reached by deterrence and incentives. The law can, however, try to influence their parents. A decision rule that is in the best interest of each particular child whose custody is contested might create parental incentives or expectations that are detrimental to the interests of children in general. The Victorian argument against giving custody to an adulterous parent is one example of this reasoning. The argument against giving custody to a parent who has used illegal tactics to exploit the status quo presumption is another. In general, it is better for

so See generally John C. Harsanyi, Rule Utilitarianism and Decision Theory, 11 Erkenntnis 25 (1977). 
children if one removes parents' incentives to create such faits accomplis.

A third example concerns the argument for family autonomy and freedom from state intervention. This problem is more relevant for child placement law than for divorce law, but is mentioned here because of its fundamental importance. If the best interest of the child is indeed the value guiding the law, one might wonder why courts or welfare agencies are not allowed to remove a child from perfectly fit biological parents when other parents are available who would provide even better for the child. ${ }^{67}$ To forbid this, it is not necessary to embrace the view that there is a fundamental, natural right to family autonomy. ${ }^{68}$ It is sufficient to point out that an act-oriented interpretation of the best interest principle would create so much uncertainty among parents, with subsequent lack of emotional attachment to their children, that the net effect would be to harm children in general. In addition there would be a strong disincentive to having children at all. ${ }^{69}$

2. Decision costs. Decision making is a costly process. It requires time, energy, and other scarce resources with alternative uses. Rational decision making that does not take account of this fact runs the risk of being self-defeating. If one focuses entirely on reaching the decision that would have been best if found instantaneously and costlessly, the occasion for acting may no longer be

${ }^{87}$ Mnookin describes a hypothetical example of this sort. See 39 L. \& Contemp. Prob. at 268 (cited in note 14). In Mnookin's further discussion of the example, however, he seems to confuse the inappropriateness of the act-oriented application of the best interest principle with its indeterminacy.

${ }^{68}$ Martin Guggenheim fails to recognize this point when he assumes that if the courts do not recognize a fundamental right to family autonomy, but offer instead "a utilitarian justification for family autonomy," there might follow "a dramatic expansion of state power in the area of child development." Martin Guggenheim, The Right to be Represented But Not Heard: Reflections on Legal Representation for Children, 59 N.Y.U. L. Rev. 76, 112 (1984). He cites with approval a statement that "if all that matters is what is most advantageous to a particular child, perhaps state intervention in parent-child relationships should be more readily allowed than it is under existing law and practices." Id. at 110, quoting Bruce C. Hafen, Children's Liberation and the New Egalitarianism: Some Reservations About Abandoning Youth to Their "Rights," 1976 B.Y.U. L. Rev. 605, 626 (1976) (emphasis added). But if what matters is what is most advantageous to children, courts would be very reluctant to interfere with family autonomy because of the uncertainty such practices would create.

${ }^{69}$ It has been argued that there was less emotional attachment to children in earlier centuries, when few of them could be expected to reach adulthood. For a brief survey of the literature on this topic, see Freeman, The Rights and Wrongs of Children at 8-13 (cited in note 18). By an ironic compensating mechanism, the poor state of medical knowledge, which was responsible for the low survival rates, also prevented family planning: if the looser emotional ties created disincentives to having children, the technology needed to act on the disincentives was absent. 
present when one finds out what it would have been optimal to do. Forecasting tomorrow's weather became a practical science only when the calculations took less than twenty-four hours.

Even when there still is an occasion to act when the solution that is optimal in the abstract has been found, the outcome may on balance be worse than if a less than optimal decision had been acted upon earlier. A rational decision maker will strive for the decision that yields the best outcome all things considered, including the costs of decision making. ${ }^{70} \mathrm{~A}$ doctor who is brought a severely hurt patient must sometimes make a snap decision about what to do, knowing that with more time he could have been sure to make the correct diagnosis, but also knowing that he does not have more time.

Because legal decisions differ from medical (or military) ones, the costs of litigation usually are not considered a reason for the judge to make snap judgments. If the law calls for a finely tuned determination of what is in the best interest of the child, the judge's task is to arrive at the decision that would have been best if found costlessly and instantaneously. ${ }^{71}$ The fact that it will be neither costless nor instantaneous is of less concern to her than arriving at the "correct" decision. She will call expert witnesses to the extent necessary; she will allow the parties to call character witnesses; she will have to allow postponements and appeals within the limits of the law. Although she may resist attempts at strategic procrastination, she cannot object to bona fide moves that just happen to be time-consuming, if she can distinguish between the two.

Parties have several incentives to procrastinate in custody litigation. A party may want to procrastinate if she has more resources than the other, so as to force the other to a more favorable private settlement. ${ }^{22}$ In addition, the longer the case, the better the chance of the party with temporary custody of gaining custody in a

70 It is often impossible to know exactly how much time is optimal to spend, but one can usually fix upper and lower limits. For an argument against the neoclassical idea that one can and should collect information up to the (uniquely determined) point at which its marginal value equals the marginal cost of collecting it, see Jon Elster, The Nature and Scope of Rational-Choice Explanation, in Ernest LePore and Brian McLaughlin, eds., Actions and Events 60-72 (1985).

71 This is a rather gross simplification, since what is in the best interest of the child may not be the same when the case is decided as it was when it was brought. The mere passing of time may give an advantage to the parent with temporary custody. Time thus has a dual effect here: by allowing the judge to gather more information it makes it easier for him to reach the best solution, but it can also affect what is the best solution.

${ }^{72}$ See Cooter and Marks with Mnookin, $11 \mathrm{~J}$. Legal Stud. at 237-40 (cited in note 15). 
legal settlement. These incentives provide an additional argument, in terms of justice to the parents, against the best interest principle. By virtue of its finely tuned character, the principle invites protracted litigation.

The main cost of a protracted litigation is, however, to the child. A custody battle places a child in many difficult roles: mediator, weapon, pawn, bargaining chip, trophy, go-between or even spy. ${ }^{73}$ Use of expert and character witnesses can be especially harmful. "The parents will call each other officially crazy, and the children will begin to wonder about themselves as well as their parents." ${ }^{\prime 4}$ Also, the "efforts of attorneys, working in an adversary spirit, can escalate conflict between parents and draw children into divorce arguments."75 Divorce seems to be more harmful to the mental health of children when dispute is contested than when it is not. $^{76}$

The best interest principle increases costs to children in two ways. First, more cases will be brought than if there existed a strong presumption rule or an automatic decision procedure because both parties may persuade themselves that they stand a chance of getting custody. Second, for any given case that is brought, the legal process will be more protracted since it is not simply a case of deciding whether one parent is unfit.

The best interest principle may, however, yield decisions that are better for the child than are automatic decisions, in the abstract sense that disregards the harm done to the child by the decision-making process itself. At least I shall proceed on this assumption, setting aside for the time being the objection from indeterminacy. The question, then, is whether children are on the whole better off by fine-tuning than under cruder principles such as automatic rules or strong presumptions. I shall select as representative of the cruder principles a strong form of the maternal

73 Andrew P. Musetto, Dilemmas in Child Custody 75, 86 (1982).

7 Goldzband, Consulting in Child Custody at 55 (cited in note 6).

${ }^{75}$ R. D. Hess and K. A. Camara, Post-Divorce Family Relationships as Mediating Factors in the Consequences of Divorce for Children, $35 \mathrm{~J}$. Soc. Issues 79-96 (1979).

${ }^{76} \mathrm{~J}$. S. Wallerstein, The Overburdened Child: Some Long-Term Consequences of Divorce, 19 Colum. J. L. \& Soc. Prob. 165-82 (1985); John Eekelaar, Children in Divorce: Some Further Data, Oxford J. Legal Stud. 63, 63-85 (1982). A study reporting no difference between the two groups of children is J. A. Elton, Parental Reports of Children's Post-Divorce Adjustment, $35 \mathrm{~J}$. Soc. Issues 126 (1979). As Elton notes, however, parental reports may not be the most reliable way to measure the mental health of the child. In any case, statistical studies of this problem must confront, as they usually do not, the problem of distinguishing between correlation and causation. Even if children suffer more when custody is contested, one cannot conclude without further argument that their suffering is caused by the dispute. 
preference rule: unless the mother is clearly unfit, she will get custody.

Assuming that some children will be better off with the father and others with the mother, but that prior to a legal and psychological examination, we do not know which children fall in which category, there are three cases to be considered. ${ }^{77}$ In the first are children who would in any case have been better off with the mother; these children can only benefit from a legal presumption that spares them the cost of litigation. The second category contains cases in which the children would have been better off with the father had there been no litigation, but will be better off with the mother if spared these costs. Finally, there may be children who, even with a legal conflict, would be better off with the father than they would be if the mother were given custody following the presumption.

Since cases in which the mother is unfit are automatically decided in the father's favor under both the best interest principle and the maternal presumption, the third category may be quite small. If it is empty, the coarse-grained maternal presumption is better for all children than the finely tuned principle of the child's best interest. But even if, as is probable, the set is not empty, the crude principle may still be better for children on the average. The answer depends on one's belief about the size of differences in parental fitness and ability of courts to assess these differences. Even if there are detectable degrees of parental fitness beyond some absolute threshold, these may not offset the pain to the child from being the object of a custody litigation.

Also, intellectual honesty should force one to recognize that there is a great deal of uncertainty surrounding the assessment of degrees of fitness, whereas the damage done to children by litigation is hardly open to doubt. Against the conjectural long-term effects on the child of being with the mother or the father, one must set the certain short-term pain and damage created by the custody dispute. ${ }^{78}$ If it is often the case that the court can say with high probability that the benefit for the child from being with one parent rather than the other is substantially greater than the pain created by litigation, fine-tuning may be justified. But even those

${ }^{77}$ The following draws upon a characteristically helpful clarification by Aanund Hylland.

${ }^{78}$ The custody struggle also may have (equally conjectural) long-term effects on the child. The child's capacity to receive affection and accord trust can be permanently stultified by this traumatic experience. 
who are not fully persuaded by the arguments presented earlier may perhaps agree that the ability of courts to make such judgments is not great.

\section{The Principle Can Be Overridden by the Public Interest}

This final consideration has a somewhat different status from the ones presented above. It will probably be accepted by most defenders of the best interest standard, as the kind of exception that can arise to the best-grounded principles. It is intended to show only that the best interest principle cannot be an absolute one. Sometimes courts must knowingly and deliberately refuse to follow what they take to be the child's best interest, on the ground that more general policy considerations take precedence.

I shall consider two ways in which the public interest might override the principle. First, imagine that one parent (I shall assume the father) has a life situation or lifestyle that is generally disapproved in the local community. The child, living with the father, would be stigmatized in a very painful way. Living with the mother would, for this reason only, be better for the child. Yet the public policy is to promote equal concern and respect for the way of life in question. To recognize popular prejudice and stigma as a factor in custody decisions is, therefore, objectionable. ${ }^{79}$ The child's welfare must, to put it crudely, be sacrificed for the greater good.

This form of sacrificing a child's best interest for reasons of public policy is best illustrated by the recent case of Palmore $v$. Sidoti, ${ }^{80}$ in which the United States Supreme Court overturned a lower court decision that had denied custody to a mother who had recently married a person of a different race. The lower court had argued that "despite the strides that have been made in bettering relations between the races in this country, it is inevitable that Melanie will, if allowed to remain in her present situation . . ., suffer from the social stigmatization that is sure to come."81 But the Supreme Court refused to allow the lower court to rely on such considerations:

The effects of racial prejudice, however real, cannot justify a

79 Chambers makes the related point that stigma to a mother caused by being denied custody should not be allowed to count as a determinant of her welfare. See 83 Mich. L. Rev. at 543-44 n.252 (cited in note 4).

so 466 U.S. 429 (1984).

s2 Id. at 431. 
racial classification removing an infant child from the custody of its natural mother. The Constitution cannot control such prejudices, but neither can it tolerate them. Private biases may be outside the reach of the law, but the law cannot, directly or indirectly, give them effect. ${ }^{82}$

Other cases, however, do ratify social prejudice under the best interest principle. An example is a British case in which a mother lost custody because she was lesbian. ${ }^{83}$ The argument of the court referred to "the risk of children, at critical ages, being exposed or introduced to ways of life which, as this case illustrates, may lead to severance from normal society, to psychological stresses and unhappiness and possibly even to physical experiences which may scar them for life." ${ }^{84}$ It is not clear whether this language refers to direct effects of the mother's sexual preference or to the indirect effects from stigma. Yet the following summary suggests that the latter were intended:

The welfare report had recommended custody to the mother on the grounds that the sexual identity of both children was well established, both children expressed wishes to be with their mother, and the mother could provide better material care for the children than the father. Both sides had called expert witnesses: for the mother it was said that 'there was no danger in this case of the children being led into deviant sexual ways'; for the father the consultant psychiatrist agreed as regards sexual deviation, but considered that the 'social embarrassment and hurt' resulting from local knowledge of their mother's lesbianism would be very harmful to the children. ${ }^{85}$

Like the state court's decision in Palmore v. Sidoti, the British court's decision to deny custody to the mother is unjustified if society accepts the right of homosexuals to equal concern and respect. Bias and stigma arising from slowness of diffusion of this attitude should not be allowed to have effect through state decisions, even if to ignore the bias will result in harm to the child.

A second example of an overriding public interest that may affect the custody decision is the financial status of the parents. The interest can be seen at work in Norway, where the financial status of the parents is not allowed to count in the custody deci-

32 Id. at 433 .

ss S v. S, 1 Fam. L. Rep. 143 (1980).

st Maidment, Custody and Divorce at 181 (cited in note 23).

ss Id. 
sion as long as both parents are above some (unspecified) minimal level. ${ }^{86}$ This principle could be seen as expressing the somewhat idealistic view that beyond a certain level of wealth the child's interest is unaffected by the resources of the parents. But, given that a basic interest of the child is to reach maturity with as many potentialities as possible, a parent has to be very affluent before further wealth makes no difference in this respect. It is more plausible to understand the principle as a statement of policy: that beyond a certain level the financial situation of the parents, while relevant for the child's best interest, should not be allowed to count. A society committed to the value of equality must often treat its citizens as if they were equal when in fact they are not. Also, courts must not give the impression that custody can be bought.

\section{Judicial Circumvention of the Best Interest Principle}

If the preceding objections to the best interest principle are accepted, one might expect courts to find it difficult to apply it literally. Consequently, one would not be surprised to see courts using a lexicographic principle of decision making: when the best interest of the child is indifferent or silent, ${ }^{87}$ give custody to the parent with the strongest rights-based or needs-based claim. Or, courts might give some weight to the interests of children in general, when the interest of the particular child in question is indeterminate.

These are not, however, lines of reasoning that have been much followed by the courts. Instead, where the best interest of the child is the dominant principle of the law, courts award custody by finding, however tortuously, a difference between the parents in this respect. The main reason is probably that courts are inherently extremely reluctant to conclude that a principle laid down in the law can be indeterminate in its application. ${ }^{88}$ In an

86 The principle is not stated in the law, but in the deliberations of the committee that prepared the reform that led to the current law. NOU 1977:35 at 64. Courts are to some extent bound by these deliberations.

${ }^{87}$ By "indifferent" I mean that both parents are deemed equally good, by "silent" that neither is deemed better than the other. In the document cited in note 86 it was suggested that courts might consider the needs of parents in cases of indifference. In the later parliamentary report, Inst. $0 . \mathrm{nr} .30(1980-81)$ at 14 , parental needs are allowed to count in cases of silence. The change must be taken to imply a tacit recognition that the best interest standard is too finely tuned.

${ }^{83}$ In addition, courts sometimes commit the theoretical fallacy of confusing indifference and silence. Assume that a court is unable to compare the parents with respect to the more important dimensions of caring, but that it can detect a clear difference in some minor respect. If the court neglects the conceptual distinction between silence and indifference, it 
important article on compromise in the law-or rather the absence of compromise-John Coons has discussed various cases in which an indeterminacy of fact or of law would seem to justify a compromise between the parties, rather than the usual winner-take-all practice of the courts. ${ }^{89}$ One of the reasons he offers to explain why compromises nevertheless occur so rarely is also relevant here. Judges might take their task less seriously if they did not have to come up with a clear-cut and definite interpretation of the law, or a clear and unambiguous statement of the facts. ${ }^{90} \mathrm{~A}$ judge is not paid to throw up his hands and say that since the law offers no guide to the decision, he will impose a compromise or, as in the present case, take account of such other considerations as seem relevant.

Therefore courts seem to follow a different strategy.91 Instead of arguing that parental interests or the interests of children in general come into play when the child's particular interest is indeterminate, they take account of these interests by making them part of the particular child's interest. I am not suggesting that judges consciously reason in this manner, only that their reasoning may be influenced by interests other than the particular child's, interests that are irrelevant under existing law but that they feel are morally pertinent or will lead to socially desirable behavior. Judges, no less than others, are vulnerable to self-deception, wishful thinking, and other forms of motivated irrationality. Although they are somewhat subject to reality control since their decisions can be appealed and reversed, their mistakes are less strongly sanctioned than those of a soldier or businessman.

This section discusses four ways in which judges can distort the best interest principle.

could then easily use this difference as the basis for awarding custody. For example, in one Norwegian case the court awarded custody mainly on the basis that the child would have a shorter walk to school from one parent's house than from that of the other. This is like seeking precision in the second decimal while remaining ignorant about the first.

so John E. Coons, Approaches to Court Imposed Compromise-The Uses of Doubt and Reason, 58 Nw. Univ. L. Rev. 750, 750-79 (1964).

: Id. at 770. For a similar argument against allowing nonunanimous jury decisions, see the dissent by Justice Douglas in Apodaca v. Oregon, 406 U.S. 404, 414 (1972).

21 The argument in the rest of this section is somewhat speculative. I hope to be able to substantiate it in a later article by a study of actual cases. From a preliminary look at some material from Norway, it would appear that lower courts are more likely to engage in these circumventing tactics. 


\section{A. Guilt and Innocence}

The idea that the "innocent"-that is, nonadulterous-party in a divorce has a special right to custody, and the closely related notion that the "guilty" party should be punished by being denied custody, largely have been eliminated from the law, but are sure to live on in the minds of many judges. They may appear explicitly in a decision, in the guise that it is not in the best interest of the child to live with a parent of loose morals. More frequently, perhaps, they contribute to the decision by making the judge weigh other parts of the evidence in a way that favors the "innocent" party.

\section{B. Caretaking}

Devoting time to child care during marriage, perhaps at great costs to personal and professional development, would seem to create in the caretaker a prima facie right to custody. Custody would be a just reward for past devotion and sacrifice. When used in modern decisions, however, the "primary caretaker" criterion is not explicitly justified on these grounds. Rather, the argument is that the primary caretaker can be expected to have the strongest emotional bonds to the child and for that reason is better fit for custody. ${ }^{92}$ In his exhaustive survey of the relevant psychological literature, David Chambers has found that on balance the support for this view is very slight. ${ }^{93}$ Judges nevertheless might be persuaded to adopt it because the rights of the primary caretakers hover in the back of their minds or because they want to promote the best interests of children in general. ${ }^{94}$

${ }^{82}$ See, for example, Garska, 278 S.E.2d at 360; Goldstein et al., In the Best Interests at 24,63 (cited in note 13).

9s Chambers, 83 Mich. L. Rev. at 527-38 (cited in note 4). At the end of his review, Chambers writes:

I have shared earlier drafts of this Article with a substantial number of persons with training in psychology or psychiatry. Nearly all acknowledge the absence of firm empirical foundation for the conclusion that preserving the bond of children to primary caretakers is more critical than preserving the bond to secondary caretakers and yet nearly all believe that there is something special in that relationship worthy of weight in making decisions about placement.

Id. at 537. Chambers adds in a footnote: "In conversations, I am never fully certain whether the psychologists are reflecting an unspoken, and perhaps unconscious, concern for the primary caretakers as well." Id. at 537 n.229. Judges, no less than psychologists, may be vulnerable to such distortion and bias.

s4 See section V below. 


\section{Creating a Fait Accompli}

The parent with temporary custody may deliberately prolong the legal process, by appeals and various legal subterfuges, so that when the decision is finally made, she can truthfully say that it would not be in the best interest of the child to have custody given to the other parent who, in the meantime, has become a psychological stranger. Illegal means such as abduction or obstruction of visitation rights can be used to the same end. In both cases, especially the latter, it seems unfair to give custody to the parent who has created the fait accompli. In addition, the decision would be counter to the interest of children in general, by rendering future procrastination, abduction, and obstruction more likely. Courts may, in such cases, rely on the general principle that no one should profit from wrongdoing. However, they also can (and do) justify their reluctance to reward such behavior by appealing to the best interest of the child: a parent who behaves in this way ipso facto reveals herself to be unfit for custody ${ }^{95}$

\section{Parental Needs}

In some cases a court might want to accord custody to the parent most in need of the child, but feel that the decision has to be justified by the best interest principle. This could take the form of arguing that if one parent will be very unhappy if not given custody, the child will suffer too. This is plausible simply by virtue of the interdependence of utility functions within the family. ${ }^{96} \mathrm{In}$ addition, the child might suffer by believing, however irrationally, that his causal involvement in the unhappiness of the parent also confers some moral responsibility on him.

The stratagems described above are not necessarily disingenuous; they may reflect valid concerns and considerations. Adultery can be one indication, among others, of moral character; primary caretaking can create a bond that ought not to be broken. A parent who kidnaps a child to get custody certainly reveals something about his character; the welfare of the parent may count so heavily in that of the child that it becomes decisive. Rather, my claim is that these arguments are easily exaggerated and made to support conclusions beyond what they can justify. The interests of parents not infrequently point in a different direction from those of a par-

\footnotetext{
's Some Norwegian cases adopting this approach are cited in Smith, Foreldremyndighet og Barnerett at 396, 418 (cited in note 35).

${ }^{28}$ Gary S. Becker, The Economic Approach to Human Behavior 270 (1976).
} 
ticular child. When one believes that the child's interests should be overridden, it ought to be possible to offer direct arguments for that conclusion instead of being compelled to dress them up as arguments about the best interest of the child. Similarly, the concern for the fate of children in general ought to be embodied in legislation rather than represented as concern for a particular child. The law might state, for instance, that illegal abduction of the child is a direct argument against giving custody to an abducting parent, whereas at present it is merely an indirect argument that the judge can use if she finds that such behavior is evidence of lack of fitness for custody.

\section{Alternatives to the Best Interest Principle}

It remains to be seen whether any other principle is superior, on balance, to the best interest standard. I shall first discuss the criteria to be used in evaluating and comparing alternative principles. As will be clear from the earlier discussion, I believe that in addition to the interest of the particular child in any given decision, one must take account of the interests of parents and of children in general. In addition to the quality of the legal decision, one also must consider the bargaining and incentive effects of the principles as well as the broader educative effects of the law.

Let me first, however, eliminate political feasibility as a criterion. One may ask, with respect to any given principle, whether it corresponds to the Zeitgeist, popular opinion or the view of Congress, and refuse to consider proposals that go against these powerful forces. Instead, I shall consider only the intrinsic merit of the proposals. In doing so, I follow the fundamental principle of intellectual argument that in discussions of economic and legal reforms, scholars should not try to preempt the decision of politicians by anticipating their reactions. If they do so, they deprive politicians of the chance to form their own considered opinions on the basis of the best available evidence and argument. ${ }^{97}$ Although in any given case the goal to be attained may be promoted by preemption and self-censorship, the long-term effect of this practice can be only to reduce the influence of professionals, intellectuals, and academics. The fact that some of the proposals discussed below-return to maternal preference or custody by the toss of a coin-are likely to

${ }^{97}$ A similar argument is made in Goldstein et al., In the Best Interests at 70 (cited in note 13), which argues that psychologists and social workers should not anticipate and internalize the judge's reasoning, but should present their views to her without self-censorship. 
meet widespread opposition is not in itself a reason for refusing to consider them.

\section{A. Criteria for Custody Rules}

In addition to the arguments that concern the quality of the legal decision, as it affects the interests of children and parents in the particular case, one may consider a number of other criteria.

1. Effects on bargaining. The bargaining effect arises because the law serves as what is known as the "threat point" in private settlements. ${ }^{98}$ By defining the outcome for the parties in the case that bargaining breaks down, the law creates a baseline with which to compare the gains from private settlement. It can make a big difference to the bargaining power of the parties whether the legal baseline for custody is a presumption rule, a form of compromise, or the strict best interest principle.

One might think that with presumption rules bargaining is simply eliminated. If maternal preference prevails, why should the mother give up in bargaining what she is sure to get in court? For one thing, the degree of her certainty depends on the strength of the presumption and, if the presumption is weak, on the likelihood that the judge will be unable to declare one parent fitter than the other. For another, bargaining over custody is usually coupled with a financial settlement. A mother may be willing to give up custody in return for a good settlement.99

2. Effects on incentives. Incentive effects could arise at various stages. After the dissolution of a marriage, a strict best interest standard supported by a status quo presumption creates incentives for procrastination and abduction. During marriage, a fault-based presumption may create a deterrence against adultery. A primary caretaker presumption creates incentives for the parents to spend time with the child, whereas the maternal preference presumption creates disincentives to do so because neither the mother nor the father is likely to gain any advantage from the extra caretaking. ${ }^{100}$ The effects on incentives might even reach back to earlier stages, before marriage and childbirth. In the unlikely event that a paternal preference rule were to be reintroduced today, one might ex-

28 Mnookin and Kornhauser, 88 Yale L. J. at 968-69 (cited in note 15); Cooter and Marks with Mnookin, 11 J. Legal Stud. at 225-32 (cited in note 15); Marc Galanter, Justice in Many Rooms, 19 J. Legal Pluralism 1-45 (1981).

92 This coupling is emphasized by Mnookin and Kornhauser, 88 Yale L. J. at 963-66 (cited in note 15), and by Weitzman, The Divorce Revolution at ch. 8 (cited in note 11).

${ }^{100}$ See text accompanying and following note 36 . 
pect to see more childless marriages and more unwed mothers. Some women might be unwilling to marry and have children if they knew that the husband would get custody in case of divorce. Other criteria that increase the probability of paternal custody can be expected to have similar, although weaker, effects.

Some of these effects on bargaining and incentives are fairly plausible, others more speculative. The conclusion that a maternal preference rule is more favorable to the mother in financial settlements than is the best interest principle seems robust, as does the view that the status quo presumption creates an incentive to strategic procrastination. When a marriage is dissolved, instrumental rationality easily becomes predominant.

On the other hand, the idea that custody rules also create incentives during the marriage itself, before it is threatened by dissolution, is more tenuous. It is far from clear that married people make a rational assessment of the probability of divorce and adjust their behavior accordingly. At the very least it seems clear that it is not in their interest to do so. Gary Becker notes that "[e]xpectations about divorce are partly self-fulfilling because a higher expected probability of divorce reduces investments in specific capital [such as children] and thereby raises the actual probability."101 From this observation one cannot conclude, of course, that people tend to have the irrationally optimistic beliefs having which is good for them. But there is other evidence that this tends to be true. ${ }^{102}$ Thus one should probably not place much emphasis on the incentive and deterrence effects of divorce rules in a marriage in which divorce is not threatening, and even less emphasis on these effects on people not yet married.

3. Educative effects. An even more tenuous argument derives from the educative and socialization effects of the law. ${ }^{103}$ These effects have been used to justify a statutory presumption for joint custody and to argue against the maternal presumption. The latter argument, for example, claims that the maternal presumption forms one link in an extensive network of formal and informal rules that tend to preempt women's choices by shaping their selfimage and career expectations. The maternal presumption, while added).

101 Becker, A Treatise on the Family at 224 (cited in note 17) (material in brackets

\footnotetext{
${ }^{102}$ See the literature cited in Elster, 24 Soc. Science Inform. at 403-06 (cited in note 52).

${ }^{103}$ For a study of the educative effects of law, see Gary B. Melton and Michael J. Saks, The Law as an Instrument of Socialization and Social Structure, in Gary B. Melton, ed., The Law as a Behavioral Instrument 237-79 (1986).
} 
superficially a right and therefore an asset, easily becomes a duty and a burden. ${ }^{104}$ On the one hand, these assertions sound plausible and may well be true. On the other hand, there is in general very little knowledge about the alleged educative effects of the law. ${ }^{105}$ This criterion, therefore, cannot be assigned great weight.

4. Process values. A final possible criterion for choosing between custody principles is related to process rather than outcome. The process values have been taken to include, among others, the following principles. For justice not only to be done but to be seen to be done, the parties must be allowed to select and present the information they deem relevant. ${ }^{108}$ Where a decision affects the "moral worth" of an individual, "adjudication . . . on the basis of documents submitted largely by third parties and by adjudicators who have never confronted the claimant seems inappropriate."107 Commenting on the proposal that child custody be decided by the toss of a coin, Robert Mnookin argues that this procedure "would deprive the parents of a process and a forum where their anger and aspirations might be expressed" and that "symbolic and participatory values of adjudication would be lost by a random process." 108

I return to Mnookin's argument below. Here I shall only make a distinction between cases in which the substantive decision is likely to be affected if one takes account of process values, and those in which essentially the same decision would be reached by a

104 The concern over whether the maternal presumption rule is in women's interest is similar to the debate regarding other laws challenged on sex discrimination grounds. Sometimes the United States Supreme Court has struck down laws that classify on the basis of gender because such laws perpetuate stereotypical sex roles. See, e.g., Orr v. Orr, 440 U.S. 268 (1979) (striking down an Alabama statute under which husbands but not wives may be required to pay alimony, noting that sex-based statutes designed to mitigate past discrimination carry the "inherent risk of reinforcing stereotypes about the proper role of women"); Califano v. Goldfarb, 430 U.S. 199 (1977) (eliminating a distinction in the Social Security Act survivors' benefits based on sex); Mississippi Univ. for Women v. Hogan, 458 U.S. 718 (1982) (university's rejection of qualified males in its School of Nursing violates equal protection). Sometimes, however, the Court has upheld sex-based laws on the ground that they compensate women for real differences. See, e.g., Califano v. Webster, 430 U.S. 313 (1977) (upholding Social Security Act provision treating women more favorably). See also Heckler v. Mathews, 465 U.S. 728 (1984) (upholding gender-based classification of the pension offset exception of the Social Security Act).

${ }^{10 s}$ For a notable exception, see Melton and Saks, in Melton, ed., The Law as a Behavioral Instrument at 237-79 (cited in note 103).

${ }^{108}$ See generally John Thibaut and Laurens Walker, A Theory of Procedure, 66 Cal. L. Rev. 541 (1978).

107 Jerry L. Mashaw, The Supreme Court's Due Process Calculus for Administrative Adjudication in Mathews v. Eldridge, 44 U. Chi. L. Rev. 28, 52 (1977).

${ }^{108}$ Mnookin, 39 L. \& Contemp. Prob. at 290 (cited in note 14). 
more circuitous and expensive route. In the latter case, the advocacy of process values amounts to arguing that justice should be both done and seen. But in the former, it comes dangerously close to arguing that it is better for something other than justice to be done and seen than for justice to be done but not seen.

\section{B. Evaluating the Alternative Rules}

In light of these various criteria-the child's interest, the interests of children, parental interests, educative effects, and process values-the following are the main alternatives to the best interest principle: (1) a return to the maternal presumption rule; (2) a primary caretaker presumption; and (3) some form of compromise between the parents. I shall consider several forms of compromise, but only one of them-the choice of a custodial parent by the flip of a coin-will be discussed in detail.

1. Return to Maternal Presumption. A number of arguments come to mind against this proposal. Children would be widely perceived to suffer if the best interest standard were abandoned. Men would oppose being deprived a fair chance of custody. Many women would object to the presumption on the grounds that it in fact burdens women.

Other women would, however, favor the maternal presumption because it would shift the balance of bargaining power towards the weaker part, and because it offers women some compensation for child care. Needless to say, the mother is not always the weaker part in divorce bargaining, nor is she invariably the primary caretaker. Nevertheless, one might argue, these generalizations are sufficiently accurate to justify a return to maternal preference.

A common response to the last set of arguments may be that the interest of parents is at best a secondary consideration, and that the interest of children is not served by a return to maternal presumption. But, if the interest of children is taken to include (as it should) their interest in being spared the pain of custody litigation, the maternal presumption's clarity and simplicity may result in net benefits to children. The case for the maternal preference becomes even stronger once one admits that the question of which parent is most fit for custody does not, in most cases, have a determinate answer. The paramount consideration then becomes the swiftness of the decision, an end to which the maternal presumption rule is well-suited.

In sum: maternal preference yields on the whole better decisions for currently living parents and for children than the best interest principle. It can be argued, however, that it presupposes 
and perpetuates sex roles, the abolition of which is in the interest of future men, women, and children.

2. A primary caretaker presumption. Two arguments are usually advanced for this principle: it gives the parents justice while also producing substantively good decisions for the child. It is a just result that the parent who has devoted the most time to the child gets custody, and it is good for the child to be with the parent who has devoted the most time to her. ${ }^{109}$

The principle could be implemented in several ways. It could be used in a very rough and ready manner, so that all-and only-parents who do not hold a full-time job and part-time working parents with a full-time working spouse could benefit from the presumption. Like the maternal presumption rule, the principle thus interpreted would be easy to implement and hence would minimize the damage done to the child by protracted litigation. Against it one might argue, first, that it does not tell the court what to do when both parents work full time, and second, that it might have the undesirable educative effect of signaling that the surest way of getting custody is to stay away from work.

The simple rule just stated, however, is not how courts and scholars have understood the primary caretaker principle. They have suggested a much more finely tuned implementation by proposing detailed criteria for what counts as caretaking. For example, the Supreme Court of West Virginia, building on Oregon decisions, has laid down ten such criteria, ranging from the preparing and planning of meals to the teaching of reading, writing, and arithmetic. ${ }^{110}$ The court's proposal invites a number of remarks.

First, among the criteria, several-the preparing and planning of meals and the purchasing, cleaning, and care of clothes-involve doing something for the child rather than doing something with 4).

109 For a thorough discussion, see Chambers, 83 Mich. L. Rev. at 527-41 (cited in note

110 See Garska, 278 S.E.2d at 363 . This decision is somewhat confused. On the one hand, it states that "intelligent determination of relative degrees of fitness requires a precision of measurement which is not possible given the tools available to the judges." Id. at 361. Thus, except when the "facts demonstrate that child care and custody were shared in an entirely equal way," the court should determine in favor of the primary caretaker. Id. at 363. Given the court's criteria for primary caretaking, the idea of demonstrating that it has been shared "in an entirely equal way" is chimerical. Id. Perhaps the court just meant to refer to cases in which there is no detectable difference between the parents-cases of silence rather than indifference. Moreover, the court virtually contradicts itself when it goes on to argue that only in the case of equal caretaking must one proceed "to inquire further into relative degrees of parental competence"-although the impossibility of the latter inquiry is stated as a reason for adopting the caretaking criterion in the first place. 
it. ${ }^{111}$ These reflect a (probably unconscious) concern for the rights of the primary caretaker, as distinct from the needs of the child, since caretaking that occurs without the child's interaction does not bring the child closer to the parent. And once activities not involving interaction are taken into account, many fathers may say that through the income they earn by working they also make a contribution to primary caretaking, in the sense of doing something for the child. To distinguish more clearly between parents, the list of criteria could be redrawn so as to include only activities that are done with the child and hence either give rise to a special need of the child for the primary caretaker or a special need of the primary caretaker for the child.112 As shown by David Chambers, however, the psychological literature gives little if any support to the notion that these needs are more important than the need for and the need of the secondary caretaker. ${ }^{113}$

Second, it may be difficult to ascertain who is the primary caretaker when both parents are working full time. Although many surveys show that the mother usually performs much more of the housework and child care in such families, ${ }^{114}$ this may not be easy to demonstrate in any given contested case, since each parent has an incentive to magnify his own efforts and to diminish those of the other. Finally, even were it possible to establish the facts in an uncontroversial manner, their interpretation might still be contested. It is not just the quantity of time spent with the child that should count: the quality of interaction is also relevant. It is easy to imagine litigation over these issues being almost as protracted, and the outcome almost as indeterminate, as when the issue at stake is the relative fitness of the parents. A finely tuned implementation of the primary caretaker criterion might not satisfy the child's interest in a swift decision.

In sum: the primary caretaking criterion, if implemented in a coarse-grained way, would minimize pain to children from custody litigation but might have undesirable socialization effects. A finely tuned implementation would not have the latter disadvantage, but neither would it recommend itself on grounds of swiftness and

11 Chambers, 83 Mich. L. Rev. at $538 \mathrm{n} .230$ (cited in note 4).

112 One could also insist on sacrifice rather than contribution as the decisive factor in awarding custody, but this would not support a primary caretaker presumption. A mother might contribute less and sacrifice more than the father, if her career opportunities were greater initially.

113 Chambers, 83 Mich. L. Rev. at 527-48 (cited in note 4).

114 See generally Richard A. Berk and Sarah Fenstermaker Berk, Labor and Leisure at Home (1979); Sarah Fenstermaker Berk, Women and Household Labor (1980). 
ease. Finally, arguments based on the needs of the primary caretaker or on the needs of children for the primary caretaker are tenuous as a matter of psychology.

3. Compromise solutions. Under this heading I discuss various solutions that depart from the winner-take-all principle usually followed in child custody proceedings. Solomon's first announced judgment represented a perverse but not infrequent form of compromise: when there is conflict over the allocation of some indivisible object, resolve it by destroying the good or, slightly less drastically, by withholding it from everybody. ${ }^{115}$ Less perverse forms of compromise include splitting siblings, giving joint custody, and randomly selecting the custodial parent.

One may compromise by splitting siblings between the parents, if each parent prefers this allocation to the alternative of the other parent getting custody of all the children. ${ }^{116}$ Not infrequently, this arrangement, when privately agreed on, takes the form of letting boys stay with the father and girls with the mother. ${ }^{117}$ It accommodates two important parental concerns: to remain a full-time parent and to share the burden of being a parent. It often will be against the interest of children, however, to split them in this way, especially if the proposal leads to one or both parents having custody of only one child. Children's moral development, and especially their sense of fairness and reciprocity, are greatly enhanced by growing up with siblings. ${ }^{118}$

The form of compromise most frequently advocated is joint custody. ${ }^{110}$ This arrangement can reconcile the interests of both

${ }^{128}$ Calabresi and Bobbit, Tragic Choices at 188, $234 \mathrm{n} .114$ (cited in note 8), refer to the "intriguing proposal" that "if all who are worthy could not receive a kidney, none should." I discuss some related phenomena in Jon Elster, Norms of Fairness (unpublished manuscript on file with The University of Chicago Law Review, 1986).

126 If this condition is not satisfied, a situation could arise in which each parent ranked the alternatives in the following order: first, I have custody of all children; second, the other parent has custody of all; third, custody is split. This corresponds to the strategic game "The Battle of the Sexes." See Luce and Raiffa, Games and Decisions at 90 (cited in note 48). The child custody conflict could also take the form of a game of "Chicken." See Anatol Rapoport, Two-Person Game Theory: The Essential Ideas 137-44 (1966). Assume, for this case, that there is one child and that each parent ranks the options in the following order: first, the other parent gets custody; second, I get custody; third, the state gets custody. (I assume, following Goldstein et al., Beyond the Best Interests at 35 (cited in note 2), that the parents can abdicate responsibility for the child, since otherwise they would have an incentive to abuse the child so as to have it taken away from them.) This situation may become increasingly frequent in one-child families with both parents working.

${ }^{127}$ For a survey of the psychological literature on the importance of matching children with a parent of the same sex, see Chambers, 83 Mich. L. Rev. at 524-27 (cited in note 4).

118 Torstein E. Eckhoff, Justice: Its Determinants in Social Interaction 356-57 (1974).

119 Joint custody can take many forms, both de facto and de jure. For an exhaustive 
parents and children-when it works. Unlike the other solutions discussed here, it is not very plausible as a court-imposed compromise. If the parents cannot agree on joint custody, there is a grave risk that the child will suffer if the court forces them to cooperate. Nevertheless, current American legislation tends to view parental agreement as neither sufficient nor necessary for joint custody awards. The nonsufficiency is justified by the risk that parents may use joint custody as a way of avoiding their responsibilities, each of them thinking that the other will bear the main burden. The nonnecessity is more paradoxical. It may be true that "[w]e have no data on the outcome of joint custody for families in which parents come to joint custody (at least initially) involuntarily or as a result of pressure from the legal system," 120 but it seems clear that a parent who is strongly opposed to a court-imposed joint custody usually will be able to sabotage it. Perhaps having a presumption for joint custody could have useful educative effects, but courts would in any case need supplementary rules about what to do when joint custody does not work.

The last alternative I shall consider is also the most controversial: to flip a coin (or, more generally, to use a randomizing device) when neither parent is unfit for custody. The proposal has been discussed, ${ }^{121}$ but to my knowledge never applied. Two preliminary points may be in order. First, in principle, one could imagine randomization being used in private settlements as well as in court-imposed decisions. ${ }^{122}$ In disputes over physically indivisible objects, bargaining theory stipulates that the set of feasible outcomes be defined as all "probability mixes" of the winner-take-all outcomes. The "solution" to the bargaining problem then will be typically that one party receives the disputed object with

survey, see the articles in Folberg, ed., Joint Custody and Shared Parenting (cited in noted 21).

${ }^{220}$ Susan Steinman, Joint Custody: What We Know, What We Have Yet to Learn, and the Judicial and Legislative Implications, in Folberg, ed., Joint Custody and Shared Parenting at 117 (cited in note 21).

${ }^{121}$ See Goldstein et al., Beyond the Best Interests at 153 n.12 (cited in note 2); Goldstein et al., In the Best Interests at 24 (cited in note 13); Mnookin, 39 L. \& Contemp. Prob. at 289 (cited in note 14); Mnookin and Kornhauser, 88 Yale L. J. at 970-71 (cited in note 15); Chambers, 83 Mich. L. Rev. at 485 (cited in note 4). On the role of randomization in general see my forthcoming Tanner lectures, Jon Elster, Taming Chance: Randomization in Individual and Social Decisions (to be delivered at Brasenose College, Oxford University, May 1987).

122 Mnookin and Kornhauser argue that when physical split of custody is impossible, there is "no middle ground" on which a compromise can be reached. 88 Yale L. J. at 975 (cited in note 15). While recognizing the possibility of court-imposed randomization, they neglect that of private randomizing. 
probability $p$ whereas the other has probability $(1-p)$ of getting it. ${ }^{123}$ In actual cases, I do not believe $p$ ever differs from one-half, either because this is the only salient or "focal" division, or because norms of fairness interfere with pure bargaining power considerations. ${ }^{124}$

The second point concerns the advantages and drawbacks of probabilistic compromise and physical compromise, by which I mean either sole custody with liberal visitation rights or some form of joint custody. Sometimes physical compromise is not feasible, if the parents live a long distance apart or are unable to get along. Even when a physical compromise is feasible, random choice of one custodial parent may be preferable. For some parents, there is increasing marginal utility in being with the child. They view time sharing as qualitatively different from, and much inferior to, a life fully shared with the child. On the other hand, if they are riskaverse, they might still prefer time sharing over random selection. In general, the net effect of these two opposed tendencies-increasing marginal utility and risk aversion-is indeterminate. Other parents have decreasing marginal utility of time spent with the child. After a point, it may even become negative. These parents may be happy to have some free time unburdened by the effort and responsibility of child care, although they would be miserable were they not involved with the child at all.

There are two main arguments for coin tossing. First, the procedure has the virtue of being simple and automatic, thus sparing the child the pain of custody litigation. The point of litigating will largely disappear, so that the number of cases brought will be drastically reduced. When a case is brought, it will be decided as soon as the judge finds that neither parent is unfit. Using simple, robust criteria for unfitness (physical neglect, physical abuse, psychic disorders), courts will be able to make swift rulings. Less damage will be imposed on fewer children. Secondly, awarding custody by the flip of a coin is fair to the parents, in that the procedure safeguards the important values of equal treatment and equal opportunity.

The main counterarguments are the following. First, one might argue that the principle is highly unfair to the parents, if

${ }^{123}$ For surveys of solution concepts, see Alvin E. Roth, Axiomatic Bargaining Theory (1979); Ehud Kalai, Solutions to the Bargaining Problem, in Leonid Hurwicz, David Schmeidler, and Hugo Sonnenschein, eds., Social Goals and Social Organization 77 (1985).

${ }^{124}$ For an experiment throwing some doubts on the distinction between salience and fairness, see Richard J. Harris and Mark A. Joyce: What's Fair? It Depends on How You Phrase the Question, 38 J. Personality \& Soc. Psychol. 165 (1980). 
one's conception of justice emphasizes equity (to each according to contribution) or need (to each according to need) rather than absolute equality. ${ }^{125} \mathrm{I}$ have argued that parental rights (equity) and welfare (need) are relevant values; they would frequently be violated by coin tossing. Next, one might question the bargaining and incentive effects of this mechanism. As under the best interest principle, mothers will be placed in a weak bargaining situation. The very real chance of losing custody might make them bargain away everything else. Also, more speculatively, the incentive to marry and have children in the first place might be weakened. Finally, the use of a coin to choose the custodial parent is certain to meet strong objections based on procedural values. I now turn to consider this last group of objections in more detail.

Robert Mnookin's argument that coin flipping would deprive the parents of a forum where their angers and aspirations might be expressed does not seem well-founded. Social psychology research does not confirm the view that aggression can be relieved by being expressed, through some form of catharsis. If anything, acting out leads to more aggression. ${ }^{128}$ Nor do I agree with Mnookin's contention that symbolic and participatory values of adjudication would be lost in a random choice mechanism. One could imagine a cointossing procedure coming to symbolize the equal worth of the parents, as well as the child's right to a speedy decision. It may well be true that "[l]aw, after all, is for the happiness of men, and some men will always be happier with the appearance of jus-

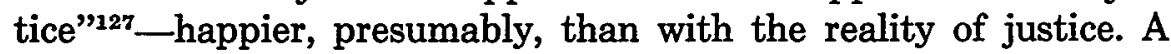
legal procedure is not viable if it strongly offends the sense of justice of a large part of the population, whatever else might be said for it. Yet if there is something to be said for it, one ought to think seriously about how it could be implemented, perhaps gradually, partially, or optionally, in ways that would not give offense. The cart of procedural justice should not be set before the horse of substantive justice. ${ }^{128}$

Many people seem to think the proposal is inhuman, frivolous,

125 These are the main conceptions usually compared in empirical studies of distributive justice. For a survey, see Morton Deutsch, Equity, Equality, and Need: What Determines Which Value Will be Used as the Basis of Distributive Justice?, 31 J. Soc. Issues 137 (1975).

${ }^{128}$ Russell G. Geen, David Stomner, and Gray L. Shope, The Facilitation of Aggression by Aggression, in Elliot Aronson, ed., The Social Animal 192 (4th ed. 1984).

${ }_{127}$ Coons, $58 \mathrm{Nw}$. Univ. L. Rev. at 771 (cited in note 89).

128 On this point I concur with the argument in Al Katz, Process Design for Selection of Hemodialysis and Organ Transplant Recipients, 22 Buff. L. Rev. 373, 391 (1973). 
or both. ${ }^{129}$ They argue that a decision with such far-reaching consequences must be made by appeal to reason and argument, not by an arbitrary choice. Coin tossing may be acceptable in trivial decisions, but not in matters of such momentous importance. On the other hand, it has been argued that "[r]andom selection is most favoured when the outcome is either of very small or very great importance to the recipients." 130 This may well be so. Examples of randomly made decisions of great importance to the recipients include draft lotteries, random allocation of kidney machines, and choices by lot of persons to be thrown overboard in an overcrowded life boat or to be eaten by the other passengers. ${ }^{131}$

One central rationale for randomization in these cases seems to be that random choice is appropriate when other criteria would force us to compare the intrinsic worth of persons. This argument also applies to custody decisions. Although the best interest analysis ostensibly scrutinizes the mother and the father only with respect to their fitness for custody, it is easily understood as a judgment on their worth more generally. But the essential point is that randomizing in custody decisions recommends itself because it has good consequences for a person other than the potential recipients-for the child.

In sum: tossing a coin to decide custody disputes shares the advantages of any automatic decision rule, in minimizing the harm done to children by protracted litigation. With regard to parents, it appeals to intuitions about equal treatment and equal worth, whereas it can violate rights-based and needs-based considerations. It shares a drawback with the best interest principle, in creating uncertainty about the final outcome so that the more risk-averse parent, usually the one for whom the child matters most, is punished by loss of bargaining power over other matters.

\section{ConcLusion}

The central premise of this article is that the current legal standard governing child custody disputes is indeterminate. In the bulk of divorce cases, there is no basis for saying that the child will

${ }^{120}$ Chambers characterizes it (without further argument) as "callous, an evasion of responsibilities both to children and to "justice." " 83 Mich. L. Rev. at 485 (cited in note 4).

${ }^{130}$ Eckhoff, Justice: Its Determinants at 305 (cited in note 118) (emphasis in original).

131 Stephen E. Fienberg, Randomization and Social Affairs: The 1970 Draft Lottery, 171 Science 255 (1971); Calabresi and Bobbit, Tragic Choices at 158, 181 (cited in note 8); J. Broome, Choosing People Randomly, 95 Ethics 38 (1984); A. W. Brian Simpson, Cannibalism and the Common Law ch. 7 (1984). 
be better off with one parent than with the other. Nevertheless, the legal regime can and should incorporate the interests of children in two ways. First, custody should not be given to a parent who is clearly unfit. Second, the pain and stress to the child created by the custody decision itself should be minimized. This second consideration points to the need for a more mechanical and automatic decision procedure than the very finely tuned best interest standard.

I have suggested and evaluated three alternatives: a strong maternal presumption, a strong primary caretaker presumption (if interpreted in a suitably coarse-grained way), and random decision making. The maternal presumption and primary caretaker rules are superior to randomization in that they compensate to some extent for the weak economic position of most women in our societies. On the other hand, these rules tend to create expectations that perpetuate the existing roles and, along with them, the weak position of women. Randomizing is in this respect inferior in the short run. Compared to the other principles, it increases the bargaining leverage of men over women. By treating the parents equally, however, it may-like the best interest standard-promote equality between the sexes over time.

The long-term educative effects are largely conjectural. By contrast, the losses suffered by women when no-fault divorce and the best interest standard were introduced around 1970 are hardly open to doubt. For many, it amounted to a change of the rules in mid-game, and to the frustration of legitimate expectations about custody and financial security. ${ }^{\mathbf{1 3 2}}$ A maternal presumption or a coarse-grained primary caretaker presumption could undo this damage. The latter rule is, however, useless for the increasing number of divorces in which both parents work full time.

The common feature of these themes is the all-pervasive presence of uncertainty about the remote consequences of present decisions. We cannot tell, in most cases, whether maternal or paternal custody will be best for any given child. Nor can we tell whether the educative and attitude-changing effects of custody law are strong enough to count heavily in legislative reform. By contrast, we do know that custody litigation imposes clear and immediate harm upon children. We also know that women in our societies labor under various disadvantages for which, until recently, divorce and custody legislation offered at least some compensation.

${ }^{132}$ See Weitzman, The Divorce Revolution at 218-35 (cited in note 11). 
While current harm done to children and harm done to currently living women do not in themselves count for more than the future gains to children and the gains to future women, they do so when the latter are discounted for the uncertainty attached to them.

No very satisfactory conclusion emerges. If the conjectural argument about the long-term educative effects is well-founded, randomization seems to be the best solution. If educative effects are minimal, a return to maternal presumption would seem to be called for. Both proposals are likely to meet strong opposition. More imaginative measures could be envisaged, such as offering marrying couples the option of binding themselves to one custody procedure or another in case they later decide to divorce and find themselves unable to agree on custody. One could even make this precommitment an obligatory feature of the marriage contract. I have neither the space nor the competence to discuss the modalities of custody reform, but I hope that I have made a case for thinking seriously about them. 